\title{
A Comparative Analysis of Social Service Provision and Accessibility in Regularised Settlements in Tanzania
}

\author{
Edmund Zakayo', Emmanuel Patroba Mhache1, Wakuru Magigi² \\ ${ }^{1}$ The Open University of Tanzania, Dar es Salaam, Tanzania \\ ${ }^{2}$ Ministry of Lands, Housing and Human Settlements Developments, Dodoma, Tanzania \\ Email: edmundzakayo@yahoo.com,emmanuel.mhache@out.ac.tz,magigi2000@yahoo.com
}

How to cite this paper: Zakayo, E., Mhache, E.P. and Magigi, W. (2019) A Comparative Analysis of Social Service Provision and Accessibility in Regularised Settlements in Tanzania. Open Access Library Journal, 6: e5278.

https://doi.org/10.4236/oalib.1105278

Received: January 28, 2019

Accepted: March 17, 2019

Published: March 20, 2019

Copyright () 2019 by author(s) and Open Access Library Inc.

This work is licensed under the Creative Commons Attribution International License (CC BY 4.0).

http://creativecommons.org/licenses/by/4.0/

\begin{abstract}
Social service provision and accessibility play a great role in ensuring city development in both developed and developing countries with emerging economies, Tanzania inclusive. This paper provides a comparative study on the situation, arguments and criticisms of three planned neighborhoods, whereby in those cases, local communities were involved in settlement upgrading through land regularization in Tanzania. The discussion centered on comparing the social infrastructure service provision and the levels of accessibility of neighborhood residents to roads, waste disposal, water and electricity supply. Similarly, the paper highlights the role of neighborhood leaders in ensuring social service provision, accessibility levels, reasons for connections, and the correlation between source of water and electricity supply as well as inferential statistics for the effects of the land regularization on the access to social services. We find that local leadership determines provision and accessibility of infrastructures in an area where informal settlement upgrading project takes place. Location differences of neighborhoods and proximity to the infrastructure service influence business growth, home improvement, service payments, and residents' mindset change in the neighborhood land development processes. We also found that conditions set for provision of social services include: availability of permanent building structure, land ownership, affordability level, household agreement, offering land for public use and freedom from the road reserve. Local Authority sets guidelines for service provision and helps meet with the local community and thus, shows the recognized role of community involvement in settlement upgrading projects. Furthermore, the role of planning institutions and differences is highlighted. The study concludes that community involvement and local leadership championship in informal settlement upgrading are vital elements for the
\end{abstract}


success of the program and towards ensuring development control, coordination and sustainability once the project ends.

\section{Subject Areas}

Sociology

\section{Keywords}

Social Services, Accessibility, Regularised Settlements, Land Regularisation

\section{Introduction}

Social service provision and accessibility in regularised planned settlements has attracted attention of many scholars, development practitioners and international organizations. Effective access to social services is a prerequisite to improving the quality of life and promoting the well-being of the people in both developed and developing countries. Access to social services is essential for health, security, livelihoods, and quality of life, and thus inadequate access to services leads to adverse health consequences [1]. In this context, social services are a range of public services provided by the government, private, and non-profit organizations for the benefit of the community and promote quality of life. These services include roads, water, electricity and solid waste management. Accessibility refers to availability and use of specific service. Social services accessibility differs from developed and developing countries. For developed countries, accessibility to social services is ensured and thus it is not the issue, while in developing countries, it is limited in many cities. The major reason for poor and unequal accessibility of social services in developing countries is failure to cope with population increase resulted from the urbanization [2] [3] [4]. Urbanization process in urban areas in both developed and developing countries is inevitable. Cities are expanding and population continues to increase. All of these require improved social services [5] [6]. Urbanization in developing countries is ungraceful due to poor plans and limited capacity for coping with such growth, as such it increases informal settlements with limited access to basic social services leading to poverty [4] [7] [8] [9] [10].

Land regularization as one of urban planning approaches ensures access to social services in informal settlements. Land regularization is a process aiming at bringing the informal and unauthorized settlements within the official, legal and administrative systems of land management through land use planning, land registration, surveying, service improvement and finally granting right of occupancy to residents in their local areas [11]. It has been accepted by International organizations, such as United Nations Development Program (UNDP), UN-Habitat and the World Bank, as a way of solving problems associated with unplanned settlements in most African, Asian and Latin American cities [12]. In 
this context, land regularization process as an urban planning tool enables urban residents in informal settlements to ensure social services, which are among indicators of local community development towards strengthening their lives [11]. Regularization as one form of land formulation process among others aims at ensuring access to social services such as roads, water, electricity, waste deposits points other information facilities and utilities through properly coordinated land use planning. The land use planning as one step in the implementation of land regularization process involves land demarcation or zoning for different uses to avoid future development conflicts and thus foster decision making and community development. It allows the construction of social services including sewer, sanitary, utilities and service provision and waste management [13]. However, the relationship between land regularization and access to basic services is not clear [14]. A number of studies suggest no relationship between land regularization projects and access to basic services due to costs associated with the provision, in other words, the provision of basic services to settlements can occur outside regularization or upgrading programs [13] [14]. As such, this provided the basis of conducting this study to find out the relationship between land regularization and access to services such as roads, water, electricity and solid waste management, in which these services are strongly connected with land regularization.

Studies on the provision of basic social services through land regularization have been conducted in different countries. In Lahore, Pakistani Wajahat [14] points that land regularization has no impact to home improvement. Access to basic services upgraded settlements are determined by the location, history, socioeconomic and political attributes of the settlements. In Senegal, Durand-Lasserve and Ndiaye [15] highlights that settlements have good access to drainage, sewerage, water supply, roads, water, electricity, septic tanks and telephone network. However, land regularization does not always result in significant improvement in access to the telephone network, electricity and water, but it depends to a large extent on investment by regularization implementing agencies. In Ghana, Nyametso [16] supports that the supply of basic social services was observed not to be necessarily related to land tenure status. Thus, even settlements with no land tenure security are able to obtain such services. In Peru, Fernandes [17] reveals that “...many legalized settlements still lack sanitation, water, utility services, infrastructure, and public spaces in some cases 10 years after their regularization". In Tanzania, Magembe-Mushi and Lupala [12] points out that in urban area residents live in informal settlements characterized by lack of the basic services of water supply, access to roads, waste water management and storm water drainage systems. As such, upgrading has been practiced in order to provide these basic services. What can be derived from the review is that access to social services and provision depend on the "bundles of powers" that individuals, local leadership, local authority and development partners hold, which are the means to control and, access to services can be achieved and sus- 
tained [18] [19]. Thus, local communities in upgraded communities should benefit from land regularization by accessing social services for improvement of their living standard. In this context, the study aimed at comparing the social infrastructure service provision and the levels of accessibility of residents to roads, waste disposal, water and electricity supply. Similarly, it also highlights the role of neighborhood leaders in ensuring social service provision, accessibility levels, reasons for connections, the correlation between source of water and electricity supply, which are critical elements in improving informal settlements in countries of Sub-Saharan Africa.

\section{The Collective Action Theory}

The study was guided by collective action theory developed by Mancur Olson in 1965. The theory explains the chance of local communities working together to achieve a common goal or public goods. It also argues that local communities do not get willingly involved in collective action unless the benefits of their involvement are more important than the costs [20]. However, Marwell and Oliver [21] provide two criticisms based on the assumption that the cost of the good is a function of the size of the group that would benefit from it, for many public goods, which is argued to be wrong. It is common that when the interest group is larger, there is a greater chance that it will include someone for whom it is rational to provide the good, either in part or in full.

\section{Study Approach and Methods}

The study was conducted in three neighborhoods namely Miembeni, Dhobi and Kwakomba neighborhoods found in Moshi municipality, Tanzania. The municipality is bordered to the north by Moshi Rural District, to the east by Mwanga District and to the south and west by the Manyara Region. According to the 2012 Tanzania National Census, the population of Miembeni is 5076, Dhobi is 5848 and Kwakomba is 4205 [22]. Also, the study found that the area size differs from one neighborhood to another. Miembeni has 42.782 hectares, Kwakomba has 14.3321 hectares and Dhobi has 18.0547 hectares.

Before selecting Miembeni, Dhobi and Kwakomba neighborhoods as the study area, there were field surveys in Moshi Municipality. The purpose was to select the area where the study could be conducted, this particularly aimed at looking at the area where upgrading through land regularisation has been implemented and initiated by residents. From there, the interview with the town planner from Moshi Municipality was carried out. The Town Planner during the survey pointed at 6 settlements where land regularization was partially done and others where it was totally initiated and implemented. These areas include Shantytown, Kwakomba, Dhobi, Pasua, Msaranga and Miembeni. From the mentioned settlements, criteria were set to select a case which is rich in information. These criteria included its accessibility within the city boundary, upgraded settlement through regularized process, completed land regularization process 
where lessons can be shared due to the fact that local communities initiated these processes using a bottom up participatory urban planning approach. From these criteria, Miembeni, Dhobi and Kwakomba settlements qualified and therefore were selected.

The study found that the study neighborhoods were dominated by Chagga (62.7\% (343)), followed by Pare (14.7\% (80) which are natives of Kilimanjaro Region. Other tribes found included Rangi, Zigua, Makonde, Nyaturu, Bondei, Hehe, Nyakyusa, Pogollo, Haya, Nyamwezi, Yao, Iraq, Kurya, Meru, Ngoni, Nyiramba, Sukuma, Tusi, Hangaza and Jita among others. Also, it was found that people have migrated from one region to another, due to economic factors including employment opportunities and business activities. In addition, it was found that $55 \%$ (300) of the respondents were peasants, $34 \%$ (186) were business men and women and only $11 \%$ (61) were employed. In urban areas, some households were found engaged in agricultural activities, especially home gardens and farms in rural areas.

The study population was 1089, and this study approached 555 respondents, including 547 heads of households from all study settlements and 3 neighborhood leaders, 1 surveyor, 2 town planners and 2 land officers who were selected through simple random and purposive. Data were collected through documentary review, interview, questionnaire and observation. Documentary review involved review of books, journals, internet, ministry reports, census reports, information from local government departments; specifically land and town planning office, and data that were originally collected for other research purposes.

Interviews were carried out which include both structured and unstructured interviews. Structured interviews and unstructured interviews were conducted with neighborhood leaders, surveyor, town planners and land officers. Structured interviews involved asking questions prepared beforehand and put in the same order to each interviewee. Unstructured interviews involved asking other questions which were raised from the respondents' response. As such, unstructured interviews were used to supplement the structured interviews in which the respondents' feelings and perceptions were noted. The study captured information related to road development, water, electricity and waste management. Other information collected was related to land regularization processes, opportunities and challenges. Similarly, information on local governance and community development as a result of land regularization processes were captured.

Questionnaires were used in data collection which entails both open and closed questions. The questionnaires were administered by a researcher during data collection from head of households. The last technique used was observation, whereby, the researcher observed roads and other basic services infrastructures, which enabled sketch maps drawings and picture taking. The questionnaires collected different data including accessibility to road before and after land regularization among households, the source of water and connection procedures at households, place of waste management as well as access to electricity supply from Tanzania Electric Supply Company Limited (TANESCO) at house- 
holds.

In addition, data analysis depended on the techniques used; such as descriptive statistics, correlation and paired sample t-test. Descriptive analysis provided a simple summary about the data in the form of frequency and percentages. Correlation as a statistical technique shows whether and how strong pairs of variables are related. The paired sample t-test was used to determine whether the mean difference between two sets of observations before and after implementation of land regularization. In this context the situation before and after land regularization was captured. It involved asking respondents to explain the situation of the social services before and after land regularization. In this respect, qualitative data were analysed through summarising (condensation) of meanings, categorisation (grouping) of meanings and structuring (ordering) of meanings using narratives. Summarising involved condensing the meaning of large amounts of text into fewer words.

\section{Findings and Discussion}

\subsection{Road Provision and Accessibility before and after Land Regularization in the Study Settlements}

Study households had different perceptions of the situation of roads before land regularization in study neighborhoods. Road facility was classified as improved, normal and poor situation. Good situation means that households were connected to road and used it in all seasons. Normal situation means that households were connected to road, but it was not used friendly, especially in rainy season; while the poor situation means that households were not connected with roads. The study findings show that $64 \%$ (363) of the respondents revealed that their roads were poor, 29\% (149) said that they were normal and only $7 \%$ (35) said that roads were improved. Table 1 shows that before land regularization, the situation of roads in Dhobi neighborhood was better compared to other study neighborhood. The situation of roads in Miembeni was poorer than other study neighborhoods. This shows that before land regularization the situation of roads was poor and thus needed improvement.

In addition, the study found that situation of roads after land regularization was different in the study neighborhoods. In Miembeni 86\% (242) of the respondents revealed that roads were improved after land regularization, compared to Kwakomba 69\% (91) and Dhobi 33\% (44). This shows that after land regularization the situation of roads in Miembeni was more improved followed by Kwakomba and in Dhobi many roads were not improved and thus continued to be poor and households had no access to roads (Table 1).

The differences of roads improvement between neighborhoods depict the role of leadership in roads improvements and construction. Neighborhoods leaders were required to organize and mobilize their residents to provide land for roads construction and improvement and participate effectively in that process by providing their labor for effective implementation. Miembeni neighborhood 
Table 1. Situation of roads before land regularization in the study neighborhoods.

\begin{tabular}{ccccccc}
\hline \multirow{2}{*}{$\begin{array}{c}\text { Situation } \\
\text { before }\end{array}$} & $\begin{array}{c}\text { Mrequency } \\
(\mathrm{n}=\mathbf{2 8 1})\end{array}$ & Percent & $\begin{array}{c}\text { Frequency } \\
(\mathrm{n}=133)\end{array}$ & Percent & $\begin{array}{c}\text { Frequency } \\
(\mathrm{n}=133)\end{array}$ & Percent \\
\hline Improved & 12 & 4 & 14 & 11 & 9 & 7 \\
Normal & 69 & 25 & 38 & 29 & 42 & 32 \\
Poor & 200 & 71 & 81 & 61 & 82 & 61 \\
Situation after & & & & & & \\
Improved & 242 & 86 & 44 & 33 & 91 & 69 \\
Not improved & 39 & 14 & 89 & 67 & 42 & 31 \\
\hline
\end{tabular}

leaders did this work as it was required and that is why level improvement and success are higher there than in other neighborhoods. This implies that with the commitment of leaders in terms of organizing and mobilizing communities, roads improvements and constructions are ensured, since the government does not have enough resources to do all these alone.

In addition, the study observed access to roads by all households (sampled and non-sampled for the study) whose plots were surveyed, found access to roads different from one neighborhood to another. In Miembeni, only one household had no access to road, while the study found that 18 (9\%) households in Miembeni and 49 (49\%) households in Dhobi were not connected to roads (Table 2).

The difference in level of access was mainly determined by leadership role in mobilizing and organizing local communities to construct and improve their roads. The study found that households being connected with roads enable easy access to basic services, especially when there is a need of using an ambulance to carry a patient, carrying sewage and others; however, this has not been achieved in Dhobi.

The study found that a land use plan and cadastral survey map in study neighborhoods show land patterns, whereby roads connecting all households in the neighborhoods were shown in the map and were required to be constructed. Since, upgrading of study neighborhoods was bottom up approach, roads were supposed to be constructed by communities in partnership with Moshi Municipal Council. Neighborhood leaders had a great role of ensuring all households are connected with roads. However, the study found that the construction of roads differs in study neighborhoods, which is reflected in numbers constructed in each neighborhood as discussed. The Municipal Council formed the Community Planning Team (CPT) to facilitate the project implementation for effective provision of social services. The team comprised 4 Technical support staff from the Moshi Municipal Council, the Ward Community workers, the Ward and neighborhood leaders, and community members elected by residents within the neighborhood making the total of team members to amount to 30 people. Also, the municipal council in cooperation with community members improved 
Table 2. Number of households connected with roads in the study neighborhoods.

\begin{tabular}{ccccccc}
\hline \multirow{2}{*}{ Response } & \multicolumn{2}{c}{ Miembeni } & \multicolumn{2}{c}{ Dhobi } & \multicolumn{2}{c}{ Kwakomba } \\
\cline { 2 - 7 } & Frequency & Percent & Frequency & Percent & Frequency & Percent \\
\hline Access & 494 & 99.8 & 307 & 86 & 193 & 91 \\
No access & 1 & 0.2 & 49 & 14 & 18 & 9 \\
Total & 495 & 100 & 356 & 100 & 211 & 100 \\
\hline
\end{tabular}

roads constructed by community members and improved existed roads to reflect urban planning standards.

In Miembeni neighborhood, leaders played a great role in ensuring that households are connected with roads. They held a number of neighborhood meetings to create awareness on the importance of being connected with road and the risk of being unconnected. This campaign was also done door to door especially for households which were not ready to contribute a land. In this campaign influential people were used to influence households who were reluctant in cooperating with neighbors, in the process of every household to be connected with roads. After, all households were connected with roads, leaders ensured that no one could block roads, so that connection of roads to all households are maintained. Thus, through community meetings, bylaws were established to control road reserves and maintain drainage infrastructures while in other neighborhoods (Dhobi and Kwakomba) leaders did not make such efforts. People were blocking roads and no initiatives were taken to stop them, unfortunately many roads were blocked, and this shows how strong leaders in land regularization are important.

In Dhobi neighborhood the situation was worse, some households are not connected to roads, there was a problem in following the land use plan, for instance roads planned to be constructed and improved were not constructed and improved. Thus some of households are not connected with roads. The formal neighborhood chairperson was involved in the land regularization process did not involve people in the land regularization process from the beginning and that is why roads were not constructed.

Therefore, access to roads among households in neighborhoods was determined by strong leadership. This is because local communities trust their leaders and are more closely with their leaders, they can meet at any time with no any cost compared to municipal officials. Leaders live with the local communities and they know the behavior of each landholder and hence they know how to influence her or him to enable construction of roads. For effectiveness of roads construction in neighborhoods, leaders should be trained and motivated to ensure achievement of land regularization. Also, municipal officials should work closely with neighborhood leaders to get information on what is going on in the neighborhood. As such, if there is no strong leadership to influence the process, then the nature and accessibility of roads will be the same like those in informal settlements. However, community members also contributed to accessibility of 
social services in kind. Community contribution was determined by labor provided and the value of land offered and the non-compensation of crops was affected during the project implementation.

\subsection{Solid Waste Disposal, Collection Points Provision and Accessibility before and after Land Regularization in the Study Settlements}

Before implementation of land regularization, households in study neighborhoods disposed solid wastes in authorised sites, which led to the eruption of diseases especially during rainy season. The implementation of the land regularization has contributed to availability of Municipal waste dump and Municipal car. In Miembeni, during land regularization, it was found that no open space could be planned for other services including sites of wastes collection, as such, one landholder provided land for such service. Since, in Kwakomba neighborhood there was no area planned for wastes collection, the Municipal Council decided to allocate car to collect wastes from households; while in Dhobi, one of the open space were authorized to be a collection point. However, the study found waste disposal behaviors in study neighborhoods differing from one study household to another. Table 3 shows that 55\% (302) of households approached dispose their solid waste to municipal waste dump, 33\% (181) dispose behind their house, and 12\% (64) collect and dispose to municipal car.

Back house excavated hole disposal in study neighborhood was found to differ from one settlement to another, for instance, in Miembeni neighborhood households excavated waste hole used for putting their waste and later firing them (Plate 1). Some of the households in Dhobi neighborhood were throwing at the back of house in special hole and firing while for other households when it is full, they dig another one.

In addition, in Dhobi neighborhood, some households were collecting wastes and employing people to take them to the municipal dump. However, the person who was paid to do that work according to the neighborhood leader was collecting bags of wastes from households and throwing them to canyon and sometime anywhere. Plate 2 shows bags of wastes deposited in canyon found in Dhobi neighborhood. Thus, the canyon is full of waste and hence produces a bad smell to adjacent households.

In Kwakomba neighborhoods, the car should pass in their streets to collect

Table 3. Waste disposal in the study neighborhoods.

\begin{tabular}{ccccccc}
\hline \multirow{2}{*}{ Location } & \multicolumn{2}{c}{ Miembeni } & \multicolumn{2}{c}{ Dhobi } & \multicolumn{2}{c}{ Kwakomba } \\
\cline { 2 - 7 } & Frequency & Percent & Frequency & Percent & Frequency & Percent \\
\hline $\begin{array}{c}\text { Municipal waste } \\
\text { dump }\end{array}$ & 158 & 56 & 107 & 80 & 37 & 28 \\
$\begin{array}{c}\text { Municipal car } \\
\text { Back house disposal }\end{array}$ & 3 & 1 & 0 & 0 & 61 & 46 \\
Total & 120 & 43 & 26 & 20 & 35 & 26 \\
\hline
\end{tabular}




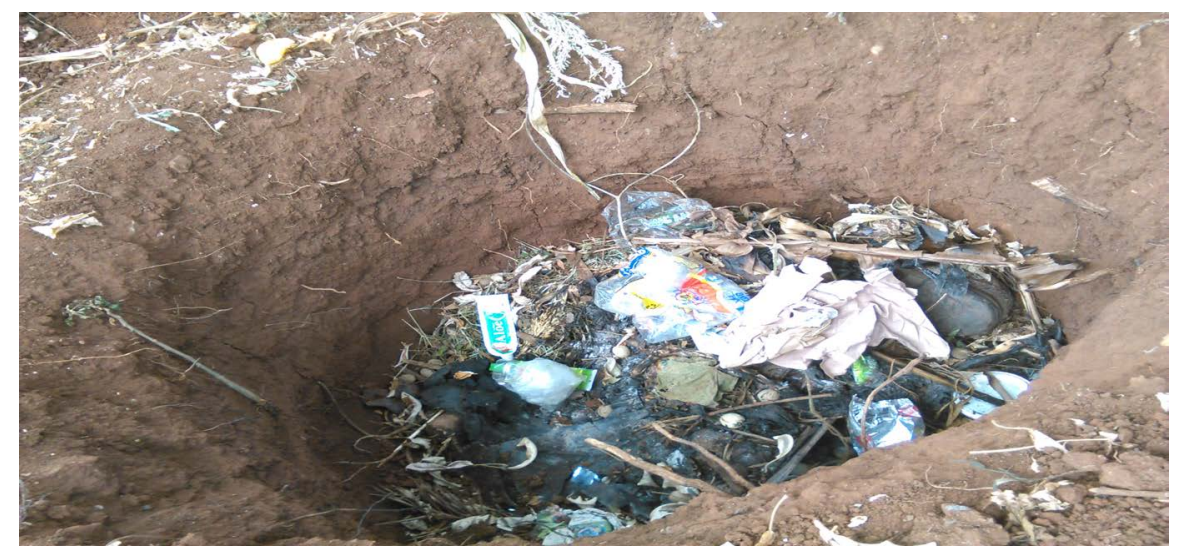

Plate 1. Back house excavated hole used for dumping solid wastes in Miembeni neighborhood.

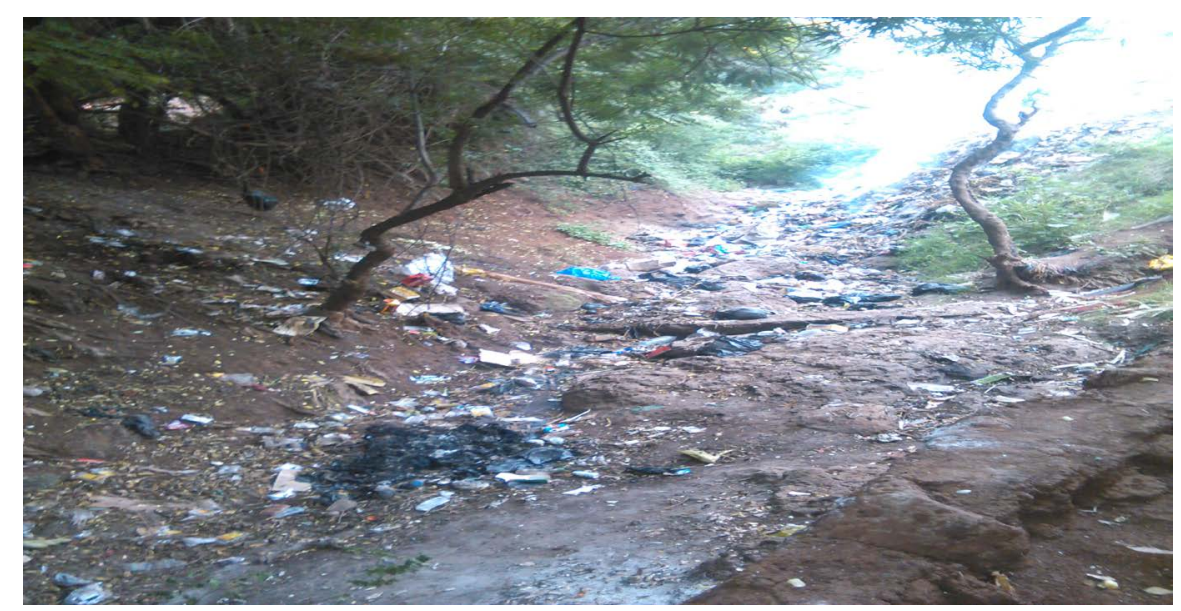

Plate 2. Bags of wastes deposited in undesignated area in Dhobi Neighborhood.

wastes twice in a week, whereby, there are special days in a week for a car to pass in their households to collect wastes accumulated and put in front of their households where municipal car pass (Plate 3).

However, it was revealed that the timetable provided is not adhered; sometimes the car may pass to the neighborhoods once a week and sometime once in two weeks. This makes wastes to stay along the roads waiting for the car which makes households uncomfortable and sometimes may lead to the outbreak of diseases.

\subsection{Water Provision and Accessibility in the Study Settlements}

The study found that $76 \%$ (417) of households were using water from Moshi Urban Water Supply Authority (MUWSA), 23\% (123) were using water from their neighbors and only $1 \%$ (7) were using water from wells (Table 4). The study revealed that households which use water from their neighbor, some buy directly when they fetch water while others share monthly water bills. This depicts the role of social capital, whereby, households interact and share some resources based on the established norms guiding their conduct. 


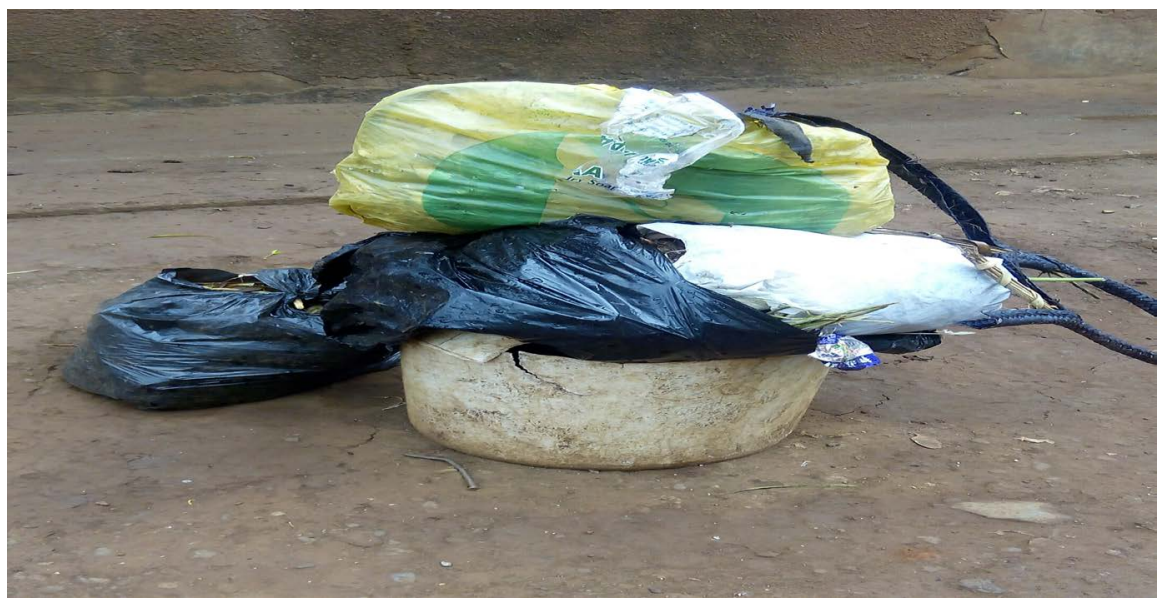

Plate 3. Dumping of solid wastes by resident along the road strips for municipal collection.

Table 4. Source of water.

\begin{tabular}{ccccccc}
\hline \multirow{2}{*}{$\begin{array}{c}\text { Source of } \\
\text { water }\end{array}$} & \multicolumn{2}{c}{ Miembeni } & \multicolumn{2}{c}{ Dhobi } & \multicolumn{2}{c}{ Kwakomba } \\
\cline { 2 - 7 } & Frequency & Percent & Frequency & Percent & Frequency & Percent \\
\hline MUWSA & 232 & 83 & 87 & 65 & 98 & 74 \\
Wells & 3 & 1 & 2 & 2 & 2 & 2 \\
Neighbors & 46 & 16 & 44 & 33 & 33 & 25 \\
Total & 281 & 100 & 133 & 100 & 133 & 100 \\
\hline
\end{tabular}

In the context of land regularization, the interview with MUWSA technician revealed that connecting water to households do not consider neighborhood status (formal and informal settlement), the important procedures include consulting the authority, and for allocation of technician to visit the household and estimate the cost associated with connecting water. The main determinant of cost is closeness of water pipe from the applicant (household), the closer the household from the water pipe, the lower the cost of connecting water. This shows that the supply of water in the neighborhoods does not have relationship to land regularization, even if the neighborhoods could be unplanned, water could be supplied, as such, water is supplied even to unplanned settlements.

\subsection{Electricity Provision and Accessibility in the Study Settlements}

In Tanzania, the electricity is supplied by Tanzania Electric Supply Company Limited (TANESCO), which is a Tanzanian Parastatal organisation established in 1964. The study findings show that $76 \%$ (416) of the respondents have access to electricity supply, and the remaining have no access to electricity (Table 5).

The main reason provided by respondents for lack of access to electricity includes financial problem. Connecting electricity requires financial resources, whereby for some of the households it becomes difficult to have that money and be connected to electricity. The cost for connecting electricity for households 
Table 5. Electricity supply.

\begin{tabular}{ccccccc}
\hline \multirow{2}{*}{ Electricity } & \multicolumn{2}{c}{ Miembeni } & \multicolumn{2}{c}{ Dhobi } & \multicolumn{2}{c}{ Kwakomba } \\
\cline { 2 - 7 } & Frequency & Percent & Frequency & Percent & Frequency & Percent \\
\hline Connected & 214 & 76 & 97 & 73 & 105 & 79 \\
Not connected & 67 & 24 & 36 & 27 & 28 & 21 \\
Total & 281 & 100 & 133 & 100 & 133 & 100 \\
\hline
\end{tabular}

which do not need electric poles is Tshs 321,000 and if there is a need of electric poles, the cost increase to more than Tshs 526,000. The study found the cost of connecting electricity does not consider the status of the settlement (formal or informal settlement). As such, interviews with TANESCO' customer care desk revealed that there is no connection between land regularization and connecting electricity to households. This shows that the electricity supply in the neighborhoods does not have relationship to land regularization, even if the neighborhoods could be unplanned, electricity could be supplied, as such, the electricity is supplied even to unplanned settlements.

\subsubsection{The Correlation between Source Water and Access to Electricity in Households}

In addition, the study found that connecting water and electricity does not consider the legal status of the neighborhoods, but ability to pay for service, compared to other services like roads and waste collection points which are compulsorily in upgraded settlements, and thus were not included in correlation analysis. Therefore, study the conducted correlation analysis to measure the relationship between the source of water at households' level and access to electricity in households. To determine whether households accessing water also have access to electricity or those who have not managed to connect water also have not managed to connect electricity, since all need financial resources. The collection, analysis shows that the Pearson's $r$ for the correlation between the between source of water at households' level and access to electricity at households is 0.487 (Table 6). This means that there is a relationship between water at households' level and access to electricity in households.

The study found positive $(+)$ this means that a household which manages to connect electricity, also manages to connect water. Similarly, as a household which manages to connect water also manages to connect electricity. Sig (2-Tailed) value is 0.000 which means that there is a statistically significant correlation between the source of water at households and access to electricity at household, since p value is less than 0.05 .

\subsubsection{Inferential Statistics for Access to Social Services}

Further analysis using Paired-Sample T-Test was done to measure the effects of the land regularization on water, roads, electricity services and waste disposal collection points, and draw conclusions by comparing the situation before and after land regulation. Table 7 shows mean number, standard deviation and 
Table 6. The correlation between source of water and access to electricity.

\begin{tabular}{cccc}
\hline & & $\begin{array}{c}\text { Source of water at your } \\
\text { households }\end{array}$ & $\begin{array}{c}\text { Access to electricity supply from } \\
\text { TANESCO at your households }\end{array}$ \\
\hline $\begin{array}{c}\text { Source of } \\
\text { water at your } \\
\text { households }\end{array}$ & Pearson Correlation & 1 & $0.487^{* *}$ \\
$\begin{array}{c}\text { Access to } \\
\text { electricity } \\
\text { supply in } \\
\text { households }\end{array}$ & Pearson Correlation & $0.487^{* *}$ & 0.000 \\
$* *$ Sig. (2-tailed) & $\mathrm{N}$ & 0.000 & 546 \\
$*$ Correlation is significant at the 0.01 level (2-tailed) & 546 & 547 \\
\hline
\end{tabular}

Table 7. Paired samples statistics for access to social services.

\begin{tabular}{|c|c|c|c|c|c|}
\hline Pair & Constructs & Mean & $\mathrm{N}$ & $\begin{array}{c}\text { Std. } \\
\text { Deviation }\end{array}$ & $\begin{array}{l}\text { Std. Error } \\
\text { Mean }\end{array}$ \\
\hline \multirow{2}{*}{ Pair 1} & $\begin{array}{l}\text { My household was connected } \\
\text { by road (before) }\end{array}$ & 2.6545 & 547 & 0.93144 & 0.03983 \\
\hline & $\begin{array}{c}\text { My household was connected } \\
\text { by road (After) }\end{array}$ & 3.9726 & 547 & 0.72449 & 0.03098 \\
\hline \multirow{2}{*}{ Pair 2} & $\begin{array}{l}\text { I was disposing my waste to the } \\
\text { Municipal waste dump (Before) }\end{array}$ & 2.5777 & 547 & 0.69198 & 0.02959 \\
\hline & $\begin{array}{l}\text { I was disposing my waste to the } \\
\text { Municipal waste dump (After) }\end{array}$ & 3.7733 & 547 & 0.68992 & 0.0295 \\
\hline \multirow{2}{*}{ Pair 3} & $\begin{array}{l}\text { My household had access } \\
\text { to water (Before) }\end{array}$ & 3.6399 & 547 & 0.63195 & 0.02702 \\
\hline & $\begin{array}{c}\text { My household had access to } \\
\text { water (After) }\end{array}$ & 3.6435 & 547 & 0.72309 & 0.03092 \\
\hline \multirow{2}{*}{ Pair 4} & $\begin{array}{l}\text { My household had access } \\
\text { to electricity (Before) }\end{array}$ & 3.6362 & 547 & 0.63275 & 0.02705 \\
\hline & $\begin{array}{l}\text { My household had access } \\
\text { to electricity (After) }\end{array}$ & 3.6307 & 547 & 0.69982 & 0.02992 \\
\hline
\end{tabular}

Before $=$ before implementation of land regularisation in study neighborhoods; After = after implementation of land regularisation in study neighborhoods.

standard error mean for constructs set showing the effects of the land regularization to access to social services before and after implementation of the land regularisation in study neighborhoods. The Mean of access to social services such as roads and waste disposal collection points was greater than mean such as services before implementation of land regularisation. However, the mean of access to water and electricity was less than the mean of access to such services before implementation of land regularization. This shows improvements of roads and waste disposal points after land regularization, while no difference for water and electricity, which implies that there is no connection as discussed earlier.

Also, the P-value for roads and waste disposal collection points (Table 8) is 0.000 , this value is less than 0.05 , while the value for water is 0.894 and for 
Table 8. Paired samples test.

\begin{tabular}{|c|c|c|c|c|c|c|c|c|c|}
\hline & \multirow{3}{*}{ Pair Construct } & \multicolumn{5}{|c|}{ Paired Differences } & \multirow{3}{*}{$\mathbf{t}$} & \multirow{3}{*}{ df } & \multirow{3}{*}{$\begin{array}{c}\text { Sig. } \\
\text { (2-tailed) }\end{array}$} \\
\hline & & \multirow[t]{2}{*}{ Mean } & \multirow{2}{*}{$\begin{array}{c}\text { Std. } \\
\text { Deviation }\end{array}$} & \multirow{2}{*}{$\begin{array}{l}\text { Std. Error } \\
\text { Mean }\end{array}$} & \multicolumn{2}{|c|}{$\begin{array}{c}95 \% \text { Confidence } \\
\text { Interval of the Difference }\end{array}$} & & & \\
\hline & & & & & Lower & Upper & & & \\
\hline Pair 1 & $\begin{array}{l}\text { My household was connected } \\
\text { by road (before) } \\
\text { My household was connected } \\
\text { by road (after) }\end{array}$ & -1.31810 & 0.87565 & 0.03744 & -1.39164 & -1.24455 & -35.206 & 546 & 0.000 \\
\hline Pair 2 & $\begin{array}{l}\text { I was disposing my waste to } \\
\text { the Municipal waste dump } \\
\text { (before) } \\
\text { I was disposing my waste to } \\
\text { the Municipal waste dump } \\
\text { (after) }\end{array}$ & -1.19561 & 0.61434 & 0.02627 & -1.24721 & -1.14401 & -45.517 & 546 & 0.000 \\
\hline Pair 3 & $\begin{array}{l}\text { My household had access to } \\
\text { water (before) } \\
\text { My household had access to } \\
\text { water (after) }\end{array}$ & -0.00366 & 0.64050 & 0.02739 & -0.05745 & 0.05014 & -0.134 & 546 & 0.894 \\
\hline Pair 4 & $\begin{array}{l}\text { My household had access to } \\
\text { electricity (before) } \\
\text { My household had access to } \\
\text { electricity (after) }\end{array}$ & 0.00548 & 0.69137 & 0.02956 & -0.05258 & 0.06355 & 0.186 & 546 & 0.853 \\
\hline
\end{tabular}

electricity is 0.0853 . This shows statistically significant difference between the access to roads and waste disposal collection points before and after implementation of the land regularisation in study neighborhoods. Also there was statistically insignificant difference between access to water and electricity before and after implementation of land regularisation in study neighborhoods. This implies that land regularization has no effect on access to water and electricity and households can be connected regardless their formality status.

\section{Reflection and Conclusion Remarks}

Reflecting the collective action theory common goal in this study is land regularization in which its benefits include access to social services, title deed acquisition and others. The study found differently on the argument that local communities do not willingly involve in collective action unless the benefits of their involvement are more important than the costs. It found that despite existing benefits from collective actions like roads and waste collection points, in Dhobi and Kwakomba neighborhoods, the study found initiatives of government and local communities in land regularization accompanied by free ride. This resulted into weak leadership that existed in mobilizing and sensitizing community members to participate effectively in the process. This implies that only the benefits and costs do not only determine willingness of local communities to participate in collective actions, but also the role of local leaders in sensitizing, organizing local communities, as well as organizing community meetings influencing the willingness for local communities to get involved in collective actions. 
The land regularization process and its output provide bases for local community development. It was found that community access to social services depends much on the land regularization output effectiveness. These include the use of land use plan, cadastral survey and title deed acquisition, which are some of the outputs to foster social service provision and business development in local communities. The community involvement at different levels was found to influence access to social services through land regularization. However, the study connects to the findings established by Payne et al. [13] who also revealed the same.

Methodological issues observed in the study include the use of the interview, particularly in capturing information relating to land regularization, opportunities and challenges. In the regards, the role of the tenants who furnished information of the landholder was revealed to be vital. Similarly, difference of cost setting in the improvement of social services such as roads, water, waste management and electricity, was noted and thus provided lessons for developing countries and development partners to contribute financial services and technical expertise to informal settlement and hence end poverty.

The study found that the accessibility of roads network after land regularization depended on the effectiveness of local leadership in mobilizing and organizing community members to improve roads and ensure all households are connected with roads. It was found that in neighborhoods with good leadership, land regularization improved and ensured roads accessibility, compared to neighborhoods with poor leadership. Waste disposal behavior among settlements with municipal car and those with dumping place differs, distance from households to authorized dumping determine the decision to whether the households should dispose their wastes. Therefore, there is a need of creating more awareness to households on waste management. This result is supported by other study [23].

Furthermore, land regularization does not stand alone and was found to require different actors. These include but not limited to, local community, government and donors, as it is very expensive to be implemented which has resulted in growth of informal settlements in Tanzania and other developing countries. This calls for different actors to support land regularization for making cities in developing countries livable. The study, therefore, concludes that community involvement and local leadership championship in informal settlement upgrading are vital elements for the success of the land regularization program and ensuring project sustainability.

\section{Conflicts of Interest}

The authors declare no conflicts of interest regarding the publication of this paper.

\section{References}

[1] Duflo, E., Galiani, S. and Mobarak, M. (2012) Improving Access to Urban Services 
for the Poor: Open Issues and a Framework for a Future Research Agenda. J-PAL Urban Services Review Paper, Cambridge, MA, Abdul Latif Jameel Poverty Action Lab.

[2] Mahendra, A. (2014) Universal Access to Affordable Housing, Social Services, and Public Utilities: Water and Sanitation, Transport, Energy and Waste Management. Final Issues Paper, 101-133.

[3] Tacoli, C., McGranahan, G. and Satterthwaite, D. (2015) Urbanisation, Rural-Urban Migration and Urban Poverty. Human Settlements Group, International Institute for Environment and Development.

[4] Zakayo, E., Mhache, E.P. and Wakuru, M. (2018) Land Regularization and Community Development Nexus in Cities of Sub Saharan Africa: A Critical Review with Urban Growth and Development Perspectives. International Journal of Scientific Research and Management, 6, No. 2. https://doi.org/10.18535/ijsrm/v6i2.g01

[5] Capello, R. (2001) Urban Growth in Italy: Economic Determinants and Socio-Environmental Consequences. International Symposium in Urban Design on "Urban Systems and Public Place". Sweden, 7-8 June 2001.

[6] Nyametso, J.K. (2010) Improvement of Squatter Settlements: The Link between Tenure Security, Access to Housing, and Improved Living and Environmental Conditions. Thesis for Award of PhD Degree at University of Otago, New Zealand, 289 p.

[7] URT (2012) Formalisation of Informal Urban Settlements in Tanzania. Property and Business Formalisation Programme, Dar es Salaam.

[8] URT (2012) Property and Business Formalization Program Experience in Formalization of Squatter Settlements; Engaging Citizens in the Process. UNPSA Forum, June 2012, New York, 52 p.

[9] Linard, C., Tatem, A.J. and Gilbert, M. (2013) Modelling Spatial Patterns of Urban Growth in Africa. Applied Geography, 44, 23-32. https://doi.org/10.1016/j.apgeog.2013.07.009

[10] IDB (2014) Comparative Evaluation: Land Regularization and Administration Projects. Office of Evaluation and Oversight, Washington DC, USA.

[11] Magigi, W. (2013) Community Involvement in Informal Settlements Upgrading: Evidence from Dar Es Salaam Metropolitan City, Tanzania. Research on Humanities and Social Sciences, 3, 75-89.

[12] Magembe-Mushi, D.L. and Lupala, J.M. (2015) Resettling Displaced Residents from Regularised Informal Settlements in Dar-es-Salaam, Tanzania: Challenges Faced by House Owners. Current Urban Studies, 3, 71. https://doi.org/10.4236/cus.2015.32007

[13] Payne, G., Durand-Lasserve, A. and Rakodi, C. (2007) Social and Economic Impacts of Land Titling Programmes in Urban and Peri-Urban Areas: A Review of the Literature. World Bank Urban Research Symposium, Washington DC, 14-16 May 2007.

[14] Wajahat, F. (2012) Tenure Security, Home Improvement and Access to Basic Services: Evidence from Informal Settlements in Lahore. Dissertation for Award of MA Degree, Florida State University.

[15] Durand-Lasserve, A. and Ndiaye, S. (2008) The Social and Economic Impact of Land Titling Programmes in Dakar, Senegal. Main Findings of the Socioeconomic Survey in Five Settlements in Dakar and Pikine. Ministry of Foreign Affairs (MFA), Government of Norway.

[16] Nyametso, J.K. (2012) The Link between Land Tenure Security, Access to Housing, 
and Improved Living and Environmental Conditions: A Study of Three Low-Income Settlements in Accra, Ghana. Norsk Geografisk Tidsskrift-Norwegian Journal of Geography, 66, 84-98. https://doi.org/10.1080/00291951.2012.665079

[17] Fernandes, E. (2011) Regularization of Informal Settlements in Latin America. Lincoln Institute of Land Policy, Cambridge.

[18] Ribot, J.C. and Peluso, N.L. (2003) A Theory of Access. Rural Sociology, 68, 153-181. https://doi.org/10.1111/j.1549-0831.2003.tb00133.x

[19] Koch, J. (2008) Perspectives on Access to and Management of Natural Resources (No. 2008: 8). DIIS Working Paper.

[20] Olson, M. (1965) The Logic of Collective Action: Public Goods and the Theory of Groups. Harvard University Press, London.

[21] Marwell, G. and Oliver, P. (1994) The Critical Mass in Collective Action: A Micro Social Theory. Public Choice, 79, 390-392.

[22] National Bureau of Statistics (2013) 2012 Population and Housing Census. Government Printers, Dar es Salaam.

[23] Schmidt, S. and Zakayo, E. (2018) Land Formalization and Local Leadership in Moshi, Tanzania. Habitat International, 74, 18-26.

https://doi.org/10.1016/j.habitatint.2018.03.001 